reconstruction will be impossible unless we first examine the system to determine whether it is united to achieve that combination of progress with security that should be the economic objective of a dynamic democracy. If we are on the wrong road, the demobilization of war-time controls will offer us our last chance to change course.

These are only some of the major questions which the stress and strain of war have brought before us and to which answers are being urgently demanded. There are many others- the wide field of building the nation's health, the readjustment of town and country life, especially for children, forced upon us by evacuation, and the new conception of colonial responsibilities to which the White Paper of a year ago gave expression. Here will be found the fields for Mr. Greenwood to plan in advance, as Mr. Churehill said in the recent debate, "a number of lárge practical steps which it is indispensable to take if our society is to move forward". The immensity of the task should be an inspiration and not a deterrent. The intensity of our concentration at the moment on the full utilization and proper distribution of the powers of production is providing us with the power to realize such plans when hostilities terminate. The expansion of industry dictated by the requirements of war is already, by the problems it creates, shaping the plan of future reconstruction. If that plan is worked out and set in motion, it will eventually, with the minimum of friction and delay, absorb the resources of production which will be released when the War comes to an end.

If therefore the call is to hard thinking and concrete planning, to the devising of appropriate machinery, drawing on the widest and wisest experience and ablest minds of the nation, it is equally one to co-operation. Mr. Churchill's plea for a continuance of national and political unity during the period immediately after the War is a sign that the Government is thinking ahead. Already it is becoming widely realized that the end of the War will be a signal, not to return to idleness and complacency, but to undertake great things. If that call is heeded, if professional men unite to bring a spirit of disinterested service, impartial inquiry and constructive thought into all those fields where their special knowledge or experience is of service, we need not despair of our ability to relieve distress and bridge the gap between war and peace, and to organize that full employment of resources which can both repair the ravages of war and usher in an ampler and nobler world order worthy of the sacrifices now being made.

\title{
RELATIONSHIP OF PURE AND APPLIED BIOLOGY
}

$\mathrm{T}$ $\mathrm{HE}$ great number and the immediacy of applied biological problems in this time of war, coupled with the embarrassingly small use made of pure biologists by those in authority, has raised acutely the problem of the relationship of pure and applied biology*. To a certain extent academic botanists and zoologists are themselves to blame for their apparent uselessness, since for long they have tended to hold themselves aloof from applied work and have, indeed, sometimes decried not only its intellectual status but even its scientific value.

This superficial and arbitrary division of biology into 'pure' and 'applied' is a very unfortunate development of comparatively recent times. For Robert Boyle, true science was such knowledge

* Discussed at a joint meeting of the Association of Applied Biologists and the Society for Experimental Biology on Friday, March 28,1941 . The opening addresses were given by Prof. P. A. Buxton and Prof. W. B. Brierley. See also pp. 436 and 439 of this issue. "as hath a tendency to use", and for Francis Bacon "such philosophy as . . . shall be operative to the endowment and betterment of man's life". So recently as the days of Pasteur there was neither 'pure' nor 'applied'; there was simply biology, botanists and zoologists increasing knowledge and adding to the sum of human welfare. But in the thirty years or so overlapping the birth of this century, a series of trends and conditions, which in themselves make a fascinating history, led to the professionalization of biology; by the early 1900's most university professors had become 'pure' biologists, and by the 1920's they had become narrow specialists in one or another branch of pure biology. Such a condition was, clearly, far from satisfactory.

So artificial, so one-sided and extreme was this development, that it stimulated a reactive movement. In 1904 the Association of Applied Bio- 
logists was founded, and although of small numbers and living a somewhat precarious existence in its early years, it survived to become the focus of a great development of application and research. In 1914 it established the Annals of Applied Biology. In 1909 the Development Fund Act was passed, and during the next fifteen years practically the whole of our present organization for applied biological research and the application of biological knowledge came into being. But the enormous growth and the very success of this organization, its wide range and the scale of its activities, only accentuated the distinction between pure and applied biology. The pure workers, fearful lest these Groths and Vandals storm their scholastic defences, or even absorb them, tended to shut themselves up like beleaguered garrisons within their ivory towers, and to develop a specialized and self-justificatory life of their own remote from the moil and toil of common life. So, to-day, there are the pure biologists holding the academic posts, and the others, the applied biologists, holding posts ranging from research institutes to commercial firms. Research institutes may be attached to universities, but, even so, their staffs are often regarded as slightly tainted.

The whole gamut of appointments from research institutes to industry is, of course, staffed by men and women trained in the universities. But, unfortunately, this is a one-way traffic system, and only in the rarest cases is there appointment of men from the applied side to the university staffs. During the last ten years the number of men who have returned to the fold can almost be counted on one hand. So, again the credo of academic men is accentuated, that they are the fount and inspiration not only of all knowledge but also of all application. As, year by year, successive vintages of students are conditioned to this belief by their academic teachers, by their academic curricula, and by every academic influence in a most formative period of their lives, so this myth lives on, rarely questioned. Occasionally, a mouse-like squeak of dissent arises, but the state of academic auto-hypnosis is little disturbed. In this connexion, academic authorities might well consider overhauling their system of appointments committees. Too often, at any rate, in the case of biology, those appointed to consider applications for academic posts are out of the field of modern research and biological advancement and should not, therefore, be put in the allimportant position of deciding the future policy of biological teaching and research through their choice of candidate. It would be a decided advantage if applied research, in the form of a biologist or biologists from an industrial or agricultural institute, were more fully represented on those committees appointed to settle appointments to senior academic positions.

Now the danger of this situation is that there is no reciprocal fertilization: applied biology receives stimulus and inspiration from research in pure biology, but the academic workers not only shut themselves off from any reverse stimulus and inspiration, but often actually seem to take pride in their isolation, a state of folly that the most casual reading of the history of science should expose. Yet their almost pathological fear of the tainting or even absorption of pure science by applied science colours their vision : they feel themselves to be crusaders defending the sanctity of pure science, which for them possesses almost a mystical quality.

The psychological motivations in this situation are fairly clear, but its immediate practical importance lies in its repercussions, the influence this situation must have on biology as a scientific discipline, on biology as a vocational training for teaching, for agriculture and horticulture, for industry and commerce, on biology as an avenue for the intellectual development of the individual, and on biology as a primary constructive factor in social life and the progress of civilization. What all biologists would deplore is that pure biology, defending its virginity, should lapse into barren spinsterhood.

A question very ripe for the asking is whether this dichotomy or antithesis of pure and applied biology serves any good purpose, or whether, recognizing its falsity, it is not imperative to attempt a reconstruction and unification of the science. Certainly if our scientific societies and our scientific journals were reconstructed and unified, we should all be very much better off financially, there would be an enormous saving of time and energy, and scientific publication and the professional organization of biology could be enormously improved. From the point of view of the research development of the subject the advantages of such a unification of the pure and applied aspects are obvious. Such a unification does not, of course, imply that the economic biologist should immediately investigate funda. mental problems, or that the theoretical biologist should undertake a modicum of commercial 
practice. It does, however, imply, especially on the part of the pure biologist, very much more give and take, much more understanding and sympathy, and a greater exercise of imagination in his contacts with mother earth. It would, for example, be perfectly simple to arrange exchange sppointments or periods of service between members of university staffs and those of research institutes, or one or another existing applied biological organization. The cross fertilizing influence of such interchange on both teaching and research would be immense.

It further implies that the academic curricula and system of training should not be regarded solely as a logical discipline, justified purely by intellectual criteria, but that attention should equally be given to biology as a factor in cultural and social life. A university degree in botany or zoology should not only be the hallmark of a competent botanist or zoologist, but it should also be the hallmark of an educated man, one capable of visualizing his biology not only as a logical system in a perspective of scientific values, but also as a means towards a fuller life in a more richly endowed social community. Pure science, guiding the student to a logical intellectualist ideal, leaves him facing the mental apparatus and not the concrete problems of life as life is lived in the world in his time. Biological teaching is only adequate when it brings biology into relation with everyday life. Biology for the biologist is totally objectionable ; biological results show their highest value by becoming the property of the people. Our traditional methods of biological education are, at best, too much occupied with intellectual analysis, at worst, too much occupied with the acquirement of formularized information; we emphasize abstract formulations and neglect their wider human applications. Praiseworthy efforts to change this are now being made by the British Social Hygiene Council, especially through its Educational Advisory Board.

Applied biology is an integral part of the vital thought and culture of our age and, as such, must be incorporated in any constructive system of higher education. The way to accomplish this is not by the insertion of so many additional courses on the several aspects of applied biology into an already overladen curriculum : students already suffer not only from intellectual strabismus, but also from chronic mental indigestion. An infinitely better way, perhaps the only satisfactory way, is to effect a thorough reconstruction of our curricula, simplifying, condensing, and pruning, eliminating all the venerable accumulations, the merely traditionalist and sentimental moieties, the moribund and dead matter, the intellectual vested interests, the fetishes and shibboleths, exercising the most stringent selection, and balancing them throughout with a more luminous vision and a more prospective imagination. For more than a generation biological teaching has been strung along the threads of logical evolutionary principles, but it should be patterned as a fabric of which the warp is the principles of logic and the woof the humane relationships of biology.

It is usually objected that all biologists, but perhaps more especially those whose leaning is towards application, must be given "a sound fundamental training", and it is always assumed that this is given by our present system. Whether this system is the only one which can do this, whether, indeed, it is the best system for this purpose, is never raised in question. Now all biologists, pure and applied, will agree that in his training a student should attain certain values, and these values are what is usually implied when the phrase "sound fundamental training" is used. But are these values anything more than the acquirement of the scientific outlook and attitude, familiarity with scientific methodology and technique, knowledge of analytic data within a recognized field and capacity to evaluate such data, and appreciation of logical scientific principles with facility in their exemplification? Does a "sound fundamental training" imply more than this and, if not, cannot these values be achieved better from biology presented as a unified and patterned fabric of development than from biology presented purely as a logical system in the traditionalist way?

Life is wider than logic, and no scientific system is sufficient unto itself. We want our students to be not merely experts in some particular branch of science, but also experts in the art and understanding of life. The improvement of natural knowledge for use is a duty as instant as that of improving natural knowledge for discovery. Science is not merely a channel of escape to a private and self-sufficient world, to be justified by remote and abstract criteria ; science is a social function, with social roots and social consequences, and if our science, if biology, is to live on as a vital human force, it must ever keep essential human values in view, and it must justify its existence in the world by its contributions to it. 